\title{
Bike-and-Ride: Build It and They Will Come
}

\author{
Robert Cervero, Benjamin Caldwell, Jesus Cuellar \\ University of California, Berkeley
}

\begin{abstract}
Converting park-and-ride to bike-and-ride trips could yield important environmental, energy conservation, and public-health benefits. While cycling in general is becoming increasingly popular in the United States, it still makes up a miniscule portion of access trips to most rail transit stations. At several rail stations of the Bay Area Rapid Transit (BART) system, 10 percent or more of access trips are by bicycle, up considerably from a decade earlier. This paper adopts a case-study approach to probe factors that have had a hand in not only cycling grabbing a larger market share of access trips to rail stops, but also in the enlargement of bike access-sheds over time. Both on-site factors, such as increases in the number of secure and protected bicycle parking racks, as well as off-site factors, such as increases in the lineal miles of separated bike-paths and bike boulevards, appear to explain growing use of bicycles for accessing rail stations. The adage "build it and they will come," we argue, holds for bicycle improvements every bit as much as other forms of urban transportation infrastructure. Pro-active partnerships between transit agencies, local municipalities, and bicycle advocacy organizations are critical to ensuring such improvements are made.
\end{abstract}

\section{The Case for Bike-and-Ride}

Bicycling is becoming increasingly popular as a way to move about American cities. Between 1977 and 2009, the total number of bike trips in the U.S. more than tripled while cycling's share of all trips nearly doubled (Pucher et al. 2011). The cycling 
renaissance is most prevalent in several dozen U.S. cities that have invested heavily in cycling infrastructure, such as Portland, Oregon, and San Francisco, where the bike's mode shares of all trips were 5.8 percent and 3.0 percent, respectively in 2009 (Pucher et al. 2011).

As a means of reaching America's rail transit stations, cycling's role remains miniscule, however. With the exception of a handful of regional rail systems, bicycles account for a fraction of one percent of all home-based access trips to most U.S. rail stops (Cervero 1995; Cervero 2003; Pucher and Buehler 2009). This is in stark contrast to countries such as Denmark and the Netherlands, where a quarter or more of all access trips to regional rail stops are by bicycle (Rietveld 2000; Martens 2004, 2007; Pucher and Buehler 2008). Shares are the highest in medium-size Dutch and Danish cities, where bikes account for 35 percent or more of access trips to rail stops (Martens 2007). In bigger cities such as Copenhagen and Amsterdam, the best habitat for bike-and-ride are suburban stations, which account for a third or more of rail access trips, even on rainy days (Cervero 2003; Martens 2004). In the U.S., walking is often preferred to cycling for reaching downtown and inner-city rail stations due to factors such as short access distances, higher risks of cycling accidents on busy streets, and limited bike parking possibilities at stations (Cervero 1995; Cervero 2003; Pucher and Buehler 2008). In suburban areas where travel distances for accessing stations tend to be longer, cycling's mobility role might be expected to increase, as in Europe; however, this has generally not been the case, partly due to the prevalence of free station-area parking coupled with the dearth of bikeways and other cycling infrastructure.

Although cycling's market share of rail access trips in the U.S. is paltry by European standards, numbers are trending upwards. Bike trips to and from bus and rail stops rose from one percent in 2001 to three percent in 2009 (Pucher et al. 2011). This upswing reflects, in good part, the complementary nature of cycling and public transit. Bicycling supports transit by extending the catchment areas of transit stops beyond a walking range, at a much lower cost than neighborhood feeder buses and park-and-ride facilities (Pucher and Buehler 2010). Upon exiting a station, bike-sharing facilities help solve the "last mile" problem. For cyclists, public transit can provide long-distance carriage and safe passage through highly-congested corridors.

What benefits would accrue for increasing cycling's role as an access mode to transit stations? For one, "active transport" modes such as cycling provide obvious personal health benefits from increased physical activity. Having more riders engage in physical activity as part of the transit trip would be a positive step toward revers- 
ing the obesity epidemic currently plaguing America (Pucher and Buehler 2010; Pucher et al. 2010). Environmental benefits would also result from converting parkand-ride trips to be bike-and-ride. Energy conservation and air-quality benefits go beyond less vehicle miles traveled (VMT). From an air quality standpoint, transit riding does little good if most people use cars to reach stations. For a three-mile automobile trip-the typical distance driven to access a suburban park-and-ride lot in the U.S. - the vast majority of hydrocarbon and nitrogen oxide emissions (the two main precursors to smog formation) are due to cold starts and hot evaporative soaks (Cervero 1995; Cervero 2001). Reliance on cars for accessing regional rail services significantly offsets the air-quality benefits of patronizing transit. Shifts from park-and-ride to bike-and-ride can also shrink surface parking lots and, thus, the amount of impervious asphalt surrounding stations. This, in turn, can reduce heat-island effects and oil-stained run-off into nearby streams, replenish local water aquifers, and bring nearby development closer to transit stops, thus creating more pedestrian-friendly surroundings. Last, investing in bike-and-ride facilities promotes social justice since many transit users have no or limited car access.

This paper investigates factors that have contributed to increased bike-and-ride activities for one particular U.S. transit agency: the San Francisco Bay Area Rapid Transit system, or BART. BART represents a best-case example, in the U.S., at least, due to proactive steps taken to increase the bicycle's role in accessing rail stations. By one account, the "San Francisco Bay Area ... has been at the vanguard of innovations to promote bike-and-ride" (Pucher and Buehler 2009, 96). Today, BART provides bike parking at almost all of its 43 stations, totaling more than 4,500 bike parking spaces and more than 1,000 secure bike lockers. Three of the 10 bike stations (that provide secure storage, short-term rentals, and on-site repairs) that existed at U.S. rail stations in 2009 were at BART stations (Pucher and Buehler 2009). Since 1990, BART's share of public transit trips combined with cycling has more than tripled due to such factors.

Taking advantage of survey data compiled by BART on bicycle access to rail stations for two time points, the analysis begins by identifying particular types of BART stations that have experienced the largest percentage increases in bike-and-ride modal shares. Several stations that achieved the largest gains are then examined in more detail to illuminate factors that likely account for these trends. Due to limited numbers of data points, the focus here is less on establishing statistical correlations and more on uncovering patterns revealed by case experiences. In addition to studying modal shares, changes in bike access-sheds are mapped and 
measured over two time points for several stations. The paper closes with discussions on policy and investment strategies for increasing the bicycle's mobility role for accessing rail stations throughout the U.S.

\section{Bikes and BART}

BART recently celebrated its 40th anniversary, making it the oldest post-WWII metropolitan rail system in the United States. With nearly 400,000 weekday trips made on a 104-mile network, BART ranked as America's fifth most patronized and third most extensive metropolitan rail network in 2012. Early on, BART was criticized for being a commuter-rail-like service masquerading as a metrorail system, owing to its long station spacings and plentiful park-and-ride provisions outside of San Francisco (Webber 1976). Vast expanses of surface parking around most of BART's suburban rail stations has also been blamed for suppressing BART's ability to spawn compact, mixed-use transit-oriented development (TOD), as envisioned when the system was first planned (Cervero and Landis 1997; Bernick and Cervero 1997). Today, surface parking remains the dominant land use immediate to the vast majority of the East Bay's suburban BART stations.

It is against this backdrop that, over the past two decades, BART planners have sought to ratchet up the mobility role of bicycles for accessing stations. This has occurred not only by providing on-site bicycle parking spaces, secure lockers, and repair facilities, but also supporting the efforts of surrounding communities to provide off-site bike-paths and bike-lanes that feed into rail stops. Also important have been auto-restraint counter-measures, introduced on-site by BART (e.g., parking charges) and off-site by local communities (e.g., traffic calming).

Collectively, these measures appear to have paid off. Between 1998 and 2008, the number of bicycle trips made to BART stations grew by 69 percent, to more than 4 percent of all access trips. This is the highest share of access trips to rail stops of any U.S. metropolitan rail system, surpassing the agency's three percent target of all access trips via bicycle set for 2010. By comparison, Washington Metrorail, a similarsize regional rail system that has also aggressively invested in bicycle infrastructure on- and near-site, averages less than 1 percent of all access trips by bicycle (Parsons Brinckerhoff 2010). Among large rail-served regions of the U.S., BART is coming as close to emulating some of Europe's bike-and-ride successes as anywhere. 


\section{Trends by Station Type}

Does the bicycle's role as an access mode vary by type of BART station? Have access roles changed over time by station types? To address these questions, data on bicycle modal shares of all home-based access trips in 1998 and 2008 were stratified by five types of BART stations. Figure 1 shows five types of stations identified by BART, defined in terms of urban setting (e.g., levels of density), parking provisions, and automobile orientation. The five station types (and number of BART stations for each type) are: Urban (9 stations); Urban with Parking (6 stations); Balanced Intermodal (10 stations); Intermodal-Auto Reliant (6 stations); and AutoDependent (12 stations). BART's Urban stations are situated in or near downtown San Francisco, Oakland, or Berkeley in dense, mixed-use settings with no parking. Urban with Parking stations lie in largely built-up neighborhoods that ring the downtowns of the same three cities and offer some off-street parking to customers. Balanced Intermodal stations are in mature suburban communities of the East Bay, with some parking and extensive feeder bus services. Intermodal-Auto Reliant stations are in largely low-density residential settings with extensive parking (thus, the "auto-reliant" title) but also with significant feeder bus connections. AutoDependent stations serve low-density bedroom communities in the suburbs of the East Bay where the private car reigns supreme, including for rail-station access.

Table 1 presents 1998 and 2008 statistical averages (and standard deviations) for bicycle access modal shares among BART stations, partitioned by each station type. Percentage point changes between the two time points are also presented (for stations that existed in both years). The table reveals significant differences in the bicycle access modal shares among the five types of BART stations for each time point as well as between the time points. A simple one-way ANOVA comparison of variations in modal shares between versus within station types shows significant differences (based on $\mathrm{F}$ statistics) for all three columns of data. In addition, the table shows that "Urban with Parking" stations-largely in fairly dense urban districts outside of downtown San Francisco, Oakland, and Berkeley, but with parking possibilities-averaged the highest bicycle access modal shares in 1998 and 2008. Moreover, these stations increased their margin of bike-access modal shares over time relative to the other four station types. Two other station types- "Urban" and "Intermodal-Auto Reliant" - also recorded respectable increases in the bicycle's station-access modal shares. In 2008, "Auto-Dependent" stations-mostly surrounded by low-density suburban residences and large surface parking lots-were the least attractive among station types for accessing BART by bicycle. 


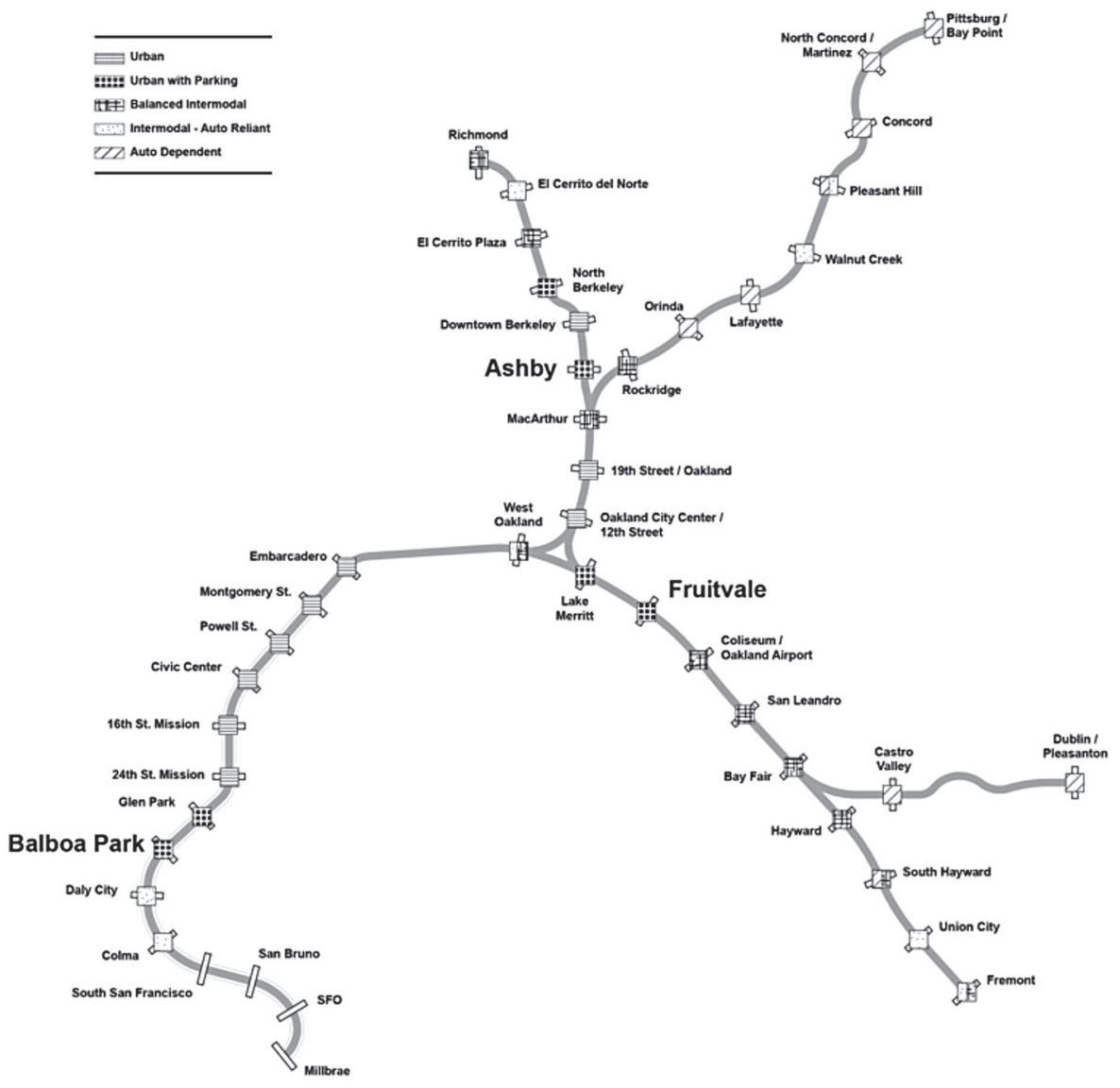

Source: BART, 2006.

Figure 1. Typology of BART station 
Table 1. Summary of BART Station Access Modal Shares by Bicycle, in Percentages, Among Five Station Types: 1998, 2008, and Changes between 1998 and 2008

\begin{tabular}{|l|c|c|c|c|}
\hline \multirow{2}{*}{ Type of Station } & \multirow{2}{*}{$\begin{array}{c}\text { No. } \\
\text { Stations }\end{array}$} & \multicolumn{3}{c|}{ Statistical Means (Std. Dev.) } \\
\cline { 3 - 5 } Urban & $\mathbf{1 9 9 8}$ & $\mathbf{2 0 0 8}$ & \% Point $\mathbf{\Delta ~ 1 9 9 8 - 2 0 0 8}$ \\
\hline Urban with Parking & 9 & $\begin{array}{c}3.42 \% \\
(2.15 \%)\end{array}$ & $\begin{array}{c}5.07 \% \\
(2.95 \%)\end{array}$ & $\begin{array}{c}1.65 \% \\
(1.82 \%)\end{array}$ \\
\hline Balanced Intermodal & 6 & $\begin{array}{c}4.14 \% \\
(2.53 \%)\end{array}$ & $\begin{array}{c}7.03 \% \\
(4.13 \%)\end{array}$ & $\begin{array}{c}2.89 \% \\
(1.93 \%)\end{array}$ \\
\hline Intermodal-Auto Reliant & 10 & $\begin{array}{c}2.67 \% \\
(0.91 \%)\end{array}$ & $\begin{array}{c}3.09 \% \\
(2.53 \%)\end{array}$ & $\begin{array}{c}0.42 \% \\
(1.90 \%)\end{array}$ \\
\hline Auto-Dependent & 5 & $\begin{array}{c}0.78 \% \\
(0.89 \%)\end{array}$ & $\begin{array}{c}2.24 \% \\
(1.75 \%)\end{array}$ & $\begin{array}{c}1.46 \% \\
(1.56 \%)\end{array}$ \\
\hline All Stations & $9 *$ & $\begin{array}{c}1.53 \% \\
(0.42 \%)\end{array}$ & $\begin{array}{c}1.67 \% \\
(0.97 \%)\end{array}$ & $\begin{array}{c}0.29 \% \\
(0.83 \%)\end{array}$ \\
\hline \hline One-way ANOVA & $39^{*}$ & $\begin{array}{c}2.57 \% \\
(1.83 \%)\end{array}$ & $\begin{array}{c}3.62 \% \\
(3.07 \%)\end{array}$ & $\begin{array}{c}1.19 \% \\
(1.82 \%)\end{array}$ \\
F Statistic (Sig.) & $39 *$ & $\begin{array}{c}4.93 \\
(.003)\end{array}$ & $\begin{array}{c}5.48 \\
(.001)\end{array}$ & $\begin{array}{c}3.01 \\
(.031)\end{array}$ \\
\hline
\end{tabular}

* Two Auto-Dependent BART stations (South San Francisco and San Bruno) did not exist in 1998 and thus are not included in the statistics for 1998 or change between 1998 and 2008 (but are included in the 2008 statistics, increasing the number of Auto-Dependent stations to 11 for that year). Also, two other BART stations (San Francisco International Airport and Millbrae) did not exist in 1998 either and thus are likewise excluded from the analysis, including for 2008, because of the absence of bicycle access options to these stations.

Source: Databases on ridership surveys compiled in 1998 and 2008 were obtained from BART planning department.

Mean statistics in Table 1 varied to a considerable degree among stations within each grouping, as revealed by standard deviations. Notably, there was fairly high variation in changes in the bicycle's modal shares between 1998 and 2008 within station groups. This indicates that a handful of stations stood out for their high levels of station-access by bike relative to other stations within the same group. Most notable are two stations in the highest scoring station type, "Urban with Parking": Ashby Station in Berkeley and Fruitvale Station in Oakland. The Ashby station, situated on the Richmond line in a transition zone between north Oakland and Berkeley (see Figure 1), averaged the highest bike shares in both 1998 (7.39\%) and 2008 (11.75\%), and also had the second-highest percentage point increase in cycling 
access (4.36) over the two time points. The station with the highest percentage point change between 1998 and 2008 was Fruitvale (5.62). The Fruitvale Station, situated on the Fremont BART line south of downtown Oakland (see Figure 1), went from the eight-highest bike-access modal share in 1998 (4.30\%) to the secondhighest in 2008 (9.92\%, second only to the Ashby station).

Clearly, some significant changes happened at these two stations over this 10-year period that made them considerably more attractive to cyclists for accessing BART. What were these? The remainder of this paper examines this question by investigating changes in on- and off-station cycling infrastructure and other policies at and around both stations over this period. In addition to associating changes to bike-access modal shares, bike-access travel-sheds are measured and mapped out in 1998 and 2008 to provide a spatial perspective to the research. Last, these two "best case" experiences are contrasted to those of the Balboa Park station in San Francisco, which was the "Urban with Parking" station that had the lowest bikeaccess modal share in 2008 (1.86\%) and recorded a fairly small increase over the 1998-2008 period (1.17 percentage points) relative to other stations in this group.

\section{Bicycle Access to Ashby BART Station}

With well over 10 percent of access trips by bicycle, the Ashby BART station is one of the top-performing bike-oriented rail stations in the U.S. Not only has the station experienced a rising share of access trips by bike, but the average distance transit riders have been willing to bike to the station has also risen, from 0.62 miles in 1998 to 1.11 miles in 2008. This 79 percent increase well exceeded the 43 percent increase in average bike-access distance for all BART stations over the same period. Longer biking distances have, in turn, translated into a vastly-enlarged bike access-shed for the Ashby station, as revealed in Figures 2 and 3 for 1998 and 2008, respectively. The maps plot Ashby BART's bike-sheds for three distance bands: 50, 75 , and 95 percentiles. The 75 percentile contour, for example, maps the outer boundary of an isochrone that captures everything from the very shortest to the 75th shortest bike access trips to the station. This means that one-quarter of bike access trips were outside of the 75th percentile access-shed. Similarly, half of bike access trips were beyond the 50th percentile bike-access shed and just 5 percent were beyond the 95th percentile shed. 


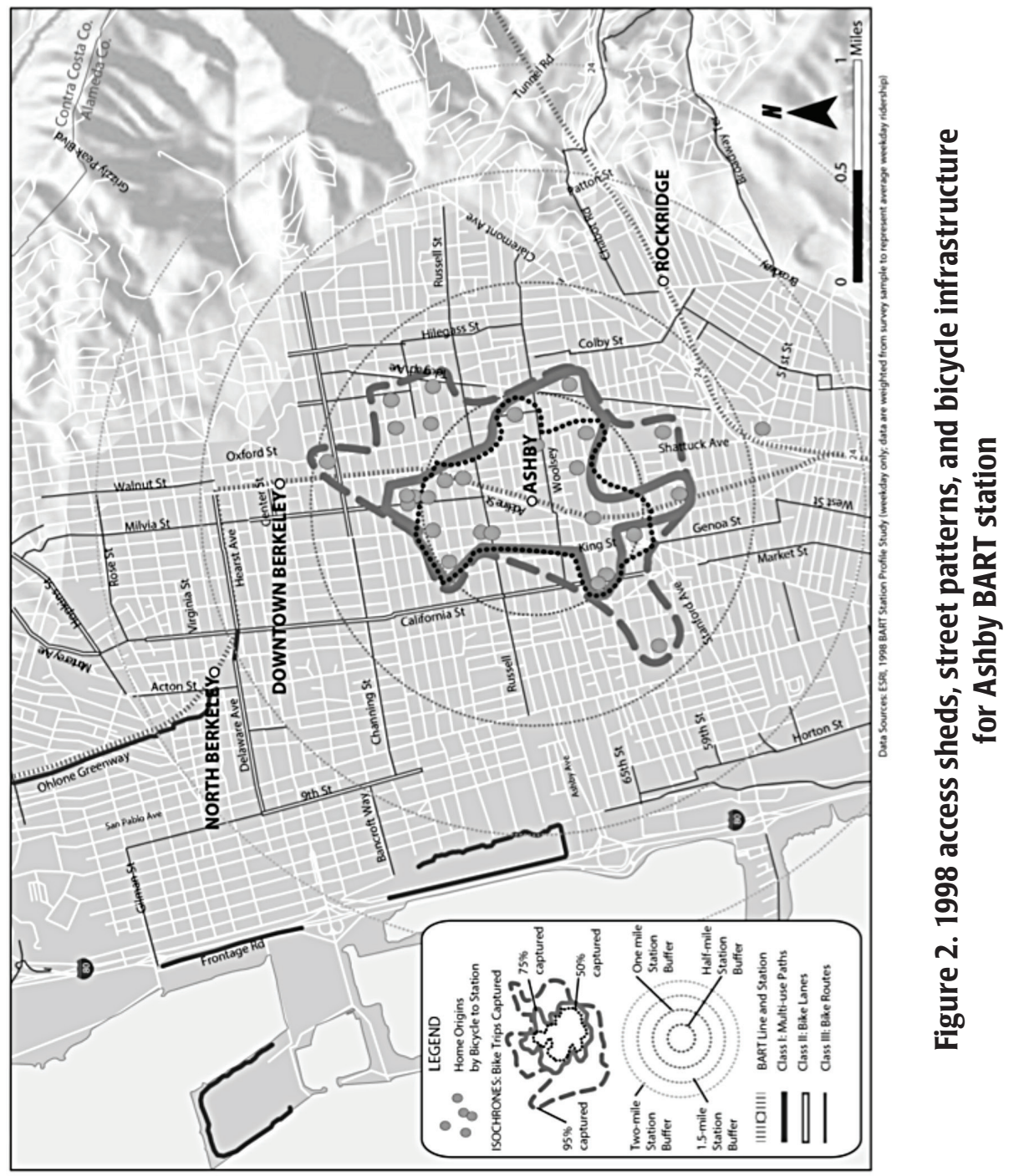




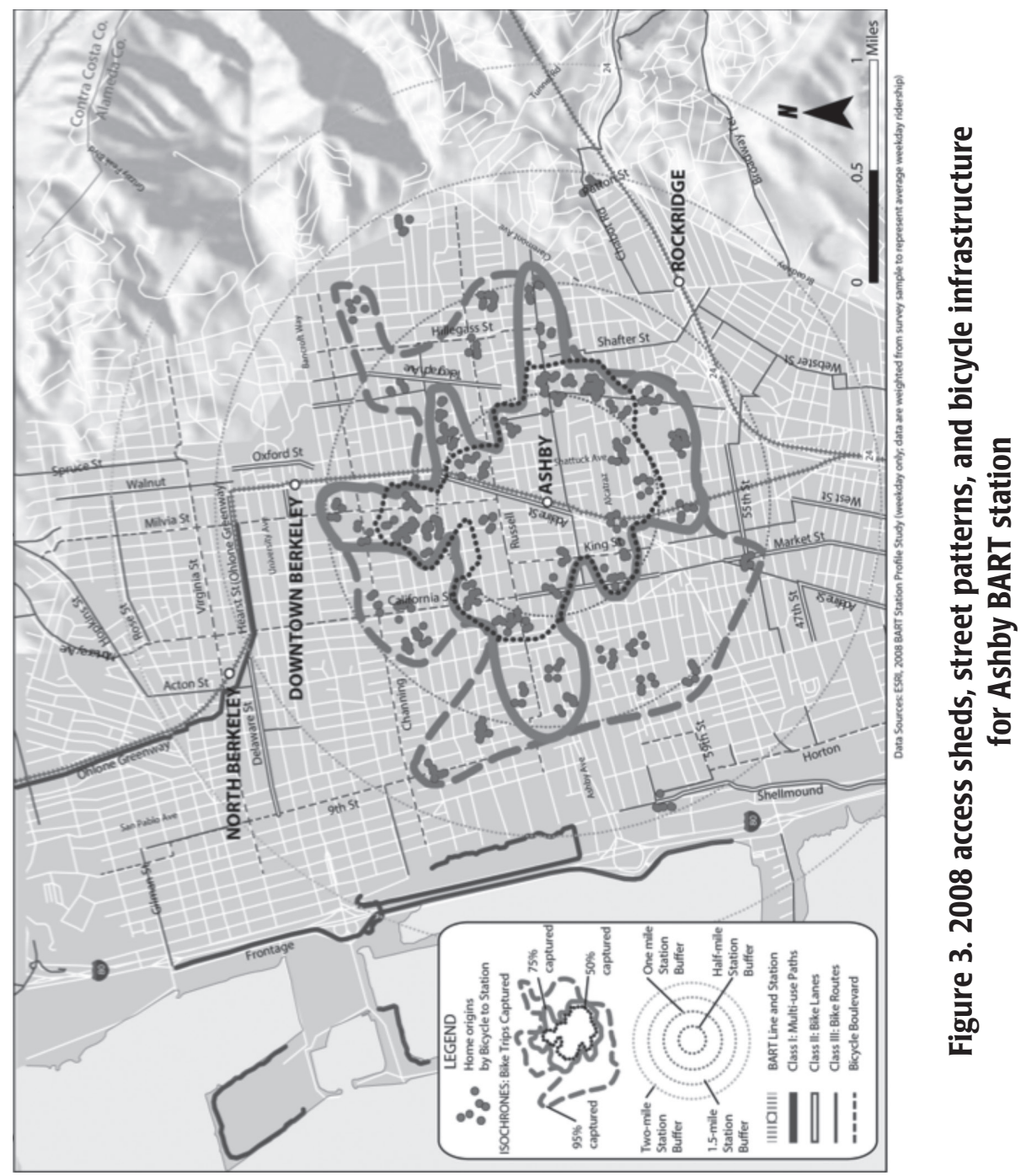


A visual scan of Figures 2 and 3 shows the amoeba-like bike access-sheds expanded outward for all three distance bands between 1998 and 2008. Table 2 reveals that the estimated land areas (in square kilometers) of the 75th percentile and 95th percentile access-sheds more than doubled over this 10-year period. Thus, not only were there higher shares of patrons accessing Ashby BART by bike in 2008 than 1998, but many were also cycling from considerably further away. If all of the bikeand-riders using Ashby BART in 2008 instead drove cars and used a park-and-ride, an estimated 83,000 additional vehicle miles would have been added to the streets of Berkeley and its surroundings that year.

\section{Table 2. Ashby BART Bike-Access Modal Shares and Estimated Access-shed Sizes: 1998, 2008, and Changes between 1998 and 2008}

\begin{tabular}{|l|c|c|c|}
\hline & $\mathbf{1 9 9 8}$ & $\mathbf{2 0 0 8}$ & $\mathbf{\Delta ~ 1 9 9 8 - 2 0 0 8}$ \\
\hline Bike Access Modal Share & $7.4 \%$ & $11.7 \%$ & $4.3 \%$ points \\
\hline Bike Access-shed Size $\left(\mathrm{km}^{2}\right)$ & & & \\
\hline 50th Percentile & 1.5 & 2.6 & $68.4 \%$ \\
\hline 75th Percentile & 1.8 & 4.1 & $128.6 \%$ \\
\hline 95th Percentile & 3.5 & 7.7 & $122.8 \%$ \\
\hline
\end{tabular}

Paralleling the dramatic increases in biking and riding at Ashby BART during the 1998-2008 period were substantial investments in high-quality bicycle infrastructure made by the city of Berkeley around the station. Figures 2 and 3 map the locations of multi-use bike paths, bike lanes (on the shoulders of streets), and bicycle routes (e.g., streets signed and sometimes traffic-calmed for cyclists) surrounding Ashby BART for the two time points. Across the three bike access-shed distance bands, Table 3 shows that the lineal kilometers of bike infrastructure surrounding Ashby BART more than doubled from 1998 and 2008, and the density of bike lanes and paths per $\mathrm{km} 2$ jumped as well. Perhaps the most notable infrastructure changes were the openings of Berkeley's network of bicycle boulevards, several of which flank Ashby as well as the city's other two BART stations. Bicycle boulevards comfort cyclists with way-finding signs as well as through various traffic calming treatments that divert or significantly slow traffic, such as intersection neck-downs, chicanes, and street tables. They have clearly benefited rail stations. The volume of mid-weekday bicycle traffic at a bicycle boulevard intersection a block and a half away from the Ashby BART station increased by 168 percent between 2000 and 2008 (Weissman 2012). Less than a quarter mile from the station, another bicycle boulevard intersection witnessed a 277 percent gain over the same period. 
Table 3. Bike Infrastructure Surrounding Ashby BART Station: 1998, 2008, and Changes between 1998 and 2008

\begin{tabular}{|l|c|c|c|}
\hline & $\mathbf{1 9 9 8}$ & $\mathbf{2 0 0 8}$ & \% $\boldsymbol{\Delta} \mathbf{1 9 9 8 - 2 0 0 8}$ \\
\hline Bike Infrastructure (lineal $\mathrm{km}$ ) & & & \\
\hline 50th Percentile Bike-shed & 2.9 & 7.9 & $172.4 \%$ \\
\hline 75th Percentile Bike-shed & 3.7 & 11.1 & $200.0 \%$ \\
\hline 95th Percentile Bike-shed & 6.2 & 19.7 & $217.7 \%$ \\
\hline Bike Infrastructure Densities (lineal km/ $\mathrm{km}^{2}$ ) & & & \\
\hline 50th Percentile Bike-shed & 1.9 & 3.0 & $57.9 \%$ \\
\hline 75th Percentile Bike-shed & 2.1 & 2.7 & $28.6 \%$ \\
\hline 95th Percentile Bike-shed & 1.8 & 2.6 & $44.4 \%$ \\
\hline
\end{tabular}

Upon arriving at Ashby BART, a system of ramps facilitates bike access to the station entrance, eliminating the need for cyclists to carry bikes up and down stairs. At the station itself are 136 protected bike-rack parking spaces, 24 secure and enclosed electronic lockers, and a recently-opened self-service bike station that accommodates 128 parked bikes. The racks and lockers were added between the two survey dates. The current count of 288 bike parking spaces at the station proper is 57 percent above what existed in 2001 (BART 2002; Eisen Letunic 2012). In addition, it now costs $\$ 1$ per day to park a car at Ashby BART, whereas a decade earlier car parking was free.

\section{Bicycle Access to Fruitvale Bart Station}

Experiences at the other "Urban with Parking" BART station that has recorded appreciable gains in bike access-Fruitvale-tell a similar story. However, unlike the Ashby Station, which caters to significant numbers of university students living in Berkeley, Fruitvale BART lies in what has long been an economically-stagnant district of Oakland, situated midway between downtown and the Oakland International Airport. Neighborhoods surrounding Fruitvale BART are also denser (nearly 25,000 persons per square mile for the census tracts abutting or surrounding the Fruitvale BART station in 2010, compared to 19,500 for tracts adjacent to Ashby BART). 
During BART's first 30 years of operations, the hoped-for transformation of the Fruitvale Station into a viable Transit Village languished and sputtered despite a series of pro-active government efforts to attract new growth and investment (Bernick and Cervero 1997; Cervero et al. 2005). Thanks to a broad-based partnership of public, private, and philanthropic interests and funding support, a compact, mixeduse village huddled around the Fruitvale Station has begun to take form over the past decade (The Unity Council 2012). In keeping with the design principles of successful transit-oriented places (Calthorpe 1993; Cervero et al. 2004), one of the signature features of the Fruitvale Transit Village has been an active public realm that is friendly to pedestrians and cyclists.

As noted previously, Fruitvale posted the largest gain-nearly 10 percentage points-in shares of access trips by bicycle among BART stations from 1998 to 2008. Its estimated bike access-sheds, shown in Figures 4 and 5 and measured in Table 4, also expanded the most. Whereas few residents of the nearby island-city of Alameda biked to Fruitvale BART in 1998, substantial numbers did in 2008, some biking several miles per day each way. Over this 10-year period, the average distance traveled by cyclists heading to Fruitvale BART increased from 1.17 to 1.75 miles, a 50 percent rise.

As part of the Transit Village campaign, a substantial amount of cycling infrastructure has been built around the Fruitvale BART station in the past decade and a half, even more so than around Ashby BART. Table 5 shows that the lineal kilometers of bike paths, bike lanes, and bike routes rose markedly during the 1998-2008 period, as did the density of surrounding bike infrastructure. Some of the surrounding bike-lanes are on heavily-trafficked arterials and, compared to Ashby BART, there is little traffic calming around the Fruitvale Station. But compared to other BART stations in Oakland, neighborhoods around the Fruitvale Station are considerably more bike-friendly. Once inside the Fruitvale Transit Village area, a wide passageway greets cyclists on the north side of the station entrance. Way-finding signs guide cyclists to the station entrance. Within the village and near the station entrance lies a 200-space, high-quality, attended Bike Station, providing secure parking, repair services, and short-term bike rentals. Along with nearby bike racks and lockers, a total of 273 safe and secure bike parking spaces today exist at the Fruitvale Station, an 81 percent increase from the early 2000s (BART 2002; Eisen Letunic 2012). Also, as with the Ashby station, there is a $\$ 1$ daily charge to park a car and ride BART. 


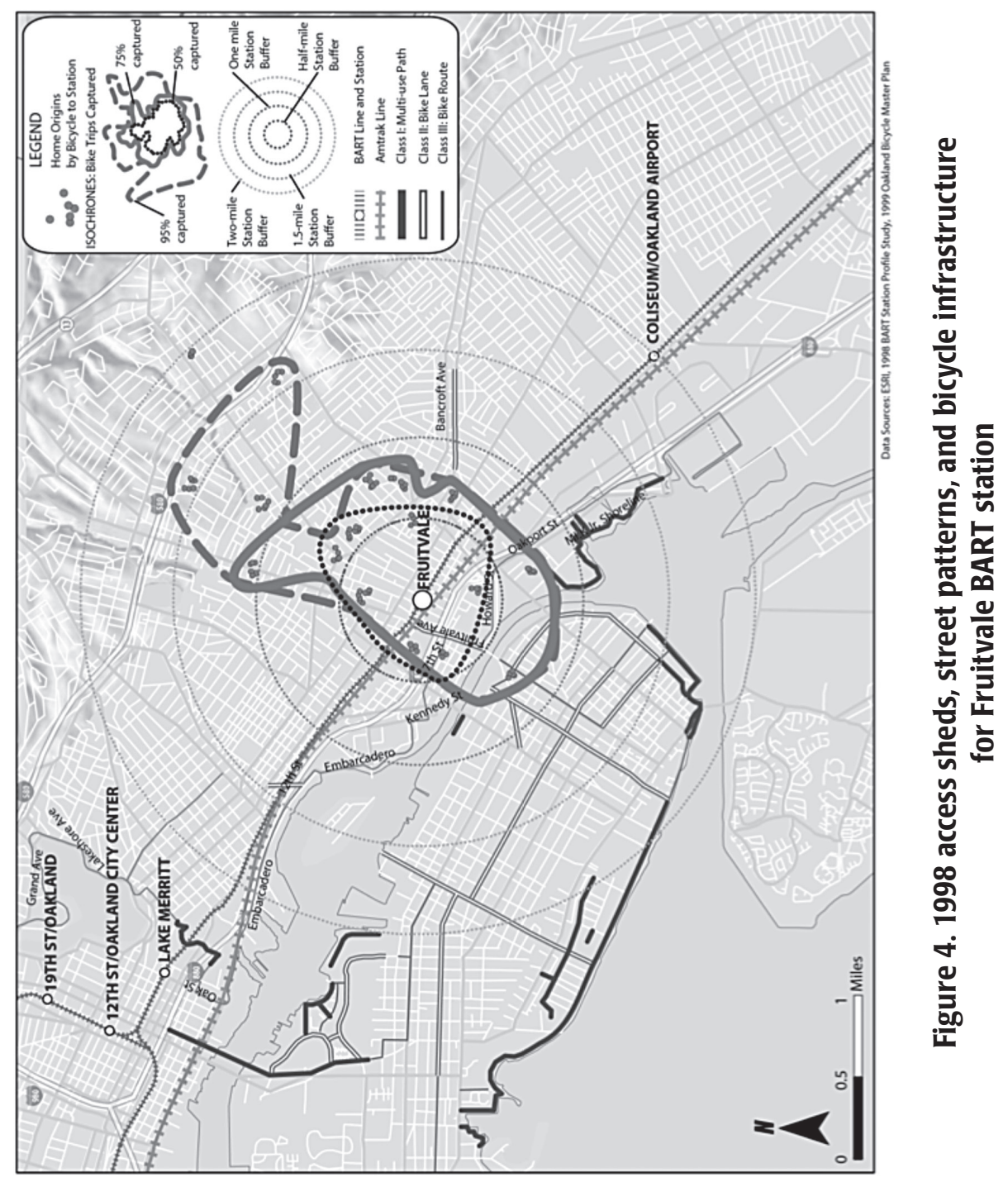




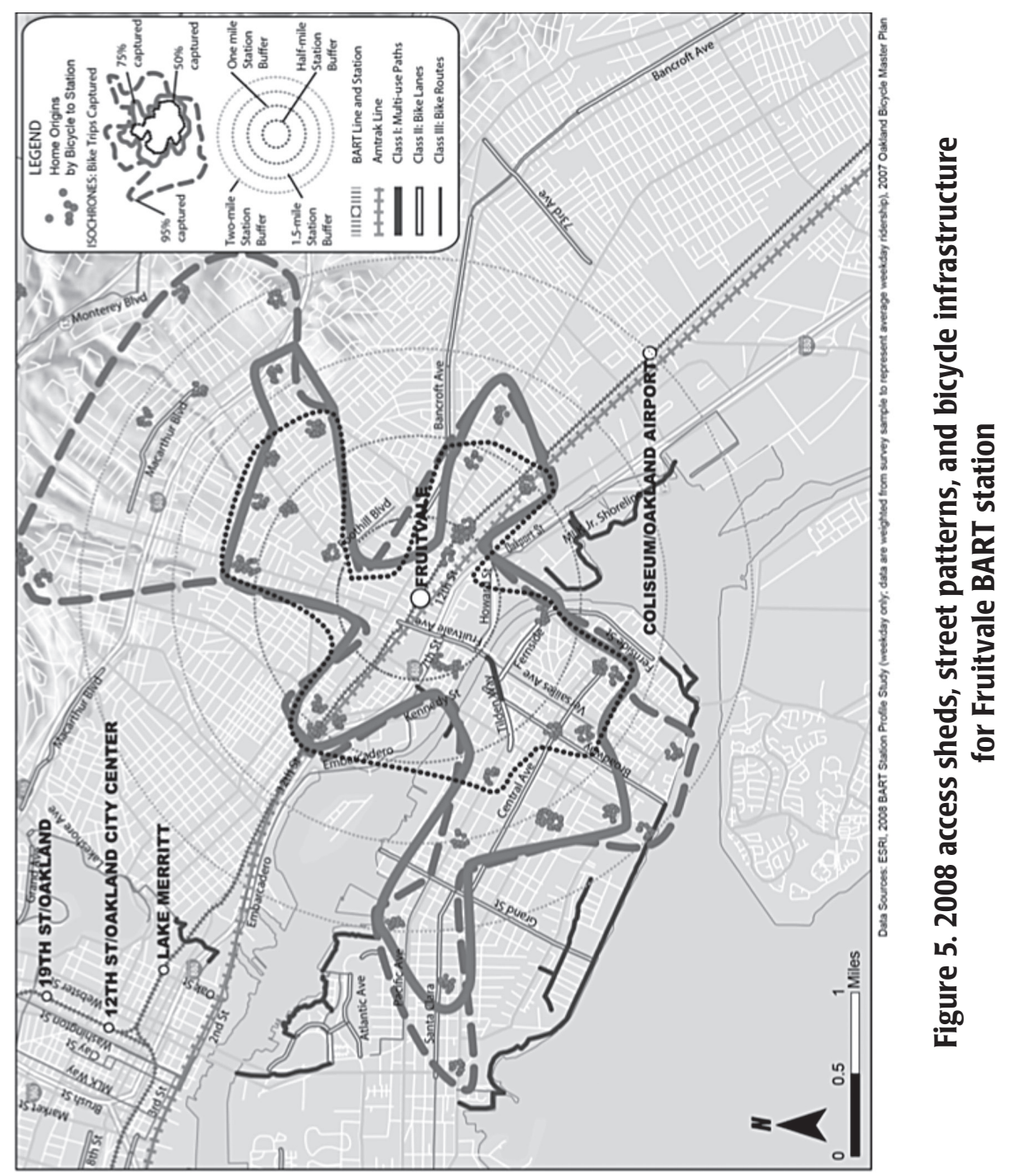


Table 4. Fruitvale BART Bike-Access Modal Shares and Access-shed Sizes: 1998, 2008, and Changes between 1998 and 2008

\begin{tabular}{|l|c|c|c|}
\hline & $\mathbf{1 9 9 8}$ & $\mathbf{2 0 0 8}$ & $\mathbf{\Delta ~ 1 9 9 8 - 2 0 0 8}$ \\
\hline Bike Access Modal Share & $4.3 \%$ & $9.9 \%$ & $5.6 \%$ points \\
\hline Bike Access-shed Size $(\mathrm{km} 2)$ & & & \\
\hline 50th Percentile & 2.4 & 9.4 & $294.0 \%$ \\
\hline 75th Percentile & 4.7 & 12.0 & $156.7 \%$ \\
\hline 95th Percentile & 6.6 & 20.6 & $210.3 \%$ \\
\hline
\end{tabular}

Table 5. Bike Infrastructure Surrounding Fruitvale BART Station: 1998, 2008, and Changes between 1998 and 2008

\begin{tabular}{|l|c|c|c|}
\hline & $\mathbf{1 9 9 8}$ & $\mathbf{2 0 0 8}$ & \% $\boldsymbol{\Delta} \mathbf{1 9 9 8 - 2 0 0 8}$ \\
\hline Bike Infrastructure (lineal $\mathrm{km}$ ) & & & \\
\hline 50th Percentile Bike-shed & 1.1 & 10.2 & $827.3 \%$ \\
\hline 75th Percentile Bike-shed & 4.0 & 13.7 & $242.5 \%$ \\
\hline 95th Percentile Bike-shed & 4.0 & 18.1 & $352.5 \%$ \\
\hline Bike Infrastructure Densities (lineal km/km2) & & & \\
\hline 50th Percentile Bike-shed & 0.4 & 1.1 & $175.0 \%$ \\
\hline 75th Percentile Bike-shed & 0.8 & 1.1 & $37.5 \%$ \\
\hline 95th Percentile Bike-shed & 0.6 & 0.9 & $50.0 \%$ \\
\hline
\end{tabular}

\section{"Worst Case" Experience}

Case-based studies as above offer advantages of transparency and real-world insights; however, they rarely provide enough quantitative ammunition to draw probabilistic inferences and make causal statements, at least in a strict sense. To strengthen the internal validity of case-based methods, best-case examples like the Ashby and Fruitvale Stations are sometimes contrasted with "worst case" examples (Yin 1994). As noted earlier, the "worst case" experience in attracting cyclists among BART stations that are "Urban with Parking" is Balboa Park BART in the city of San Francisco (see Figure 1). The term "worst" is comparative since even though Balboa Park's 1.9 percent bike modal split was the lowest among "Urban with Parking" stations in 2008, relative to all BART stations, this modal split was in the middle of the pack and relative to many other rail stations across the U.S., this is a respectable figure. Moreover, the Balboa Park Station recorded a 1.2 percentage point gain 
in the share of access trips by bike over this 10-year period. It should be noted as well that Balboa Park's relatively modest levels of bicycle access and egress are likely due, in part, to factors that encourage transit access, including high-quality feeder bus services with discounted transfers. Nonetheless, among BART's "Urban with Parking" stations, it was the least popular with cyclists.

The increase in bike-access modal shares at Balboa Park BART is likely associated with increases in on-site bike parking, from 47 spaces in 2001 to 100 spaces today (BART 2002; Eisen Letunic 2012). Unlike the Ashby and Fruitvale Stations, however, there is no full-service bike station at Balboa Park BART. Where the Balboa Park station most markedly differs from the two best-case examples is in the amount of bike infrastructure built off-site. Figures 6 and 7 map bicycle infrastructure as well as the three bands of bike access-sheds for Balboa Park BART in 1998 and 2008. Comparatively modest amounts of bicycle infrastructure were built around the Balboa Park station over this 10 -year period, which was matched by geographicallyconstrained bike access-sheds that did not expand much over this period. In 2008, Balboa Park BART had around one-third as many lineal kilometers of bike paths and bike lanes within its 75th and 95th percentile bike access-sheds as did the Ashby and Fruitvale stations.

In sum, the Balboa Park Station recorded a respectable gain in bike access modal shares over the study period; however, its bike access-shed did not grow nearly as much as those of the Ashby and Fruitvale stations. On-site bicycle parking improvements likely encouraged more nearby residents to bike-and-ride, but the minimal amount of off-site bicycle infrastructure that was built failed to enlarge the station's bike access-shed and draw in more bike customers. 


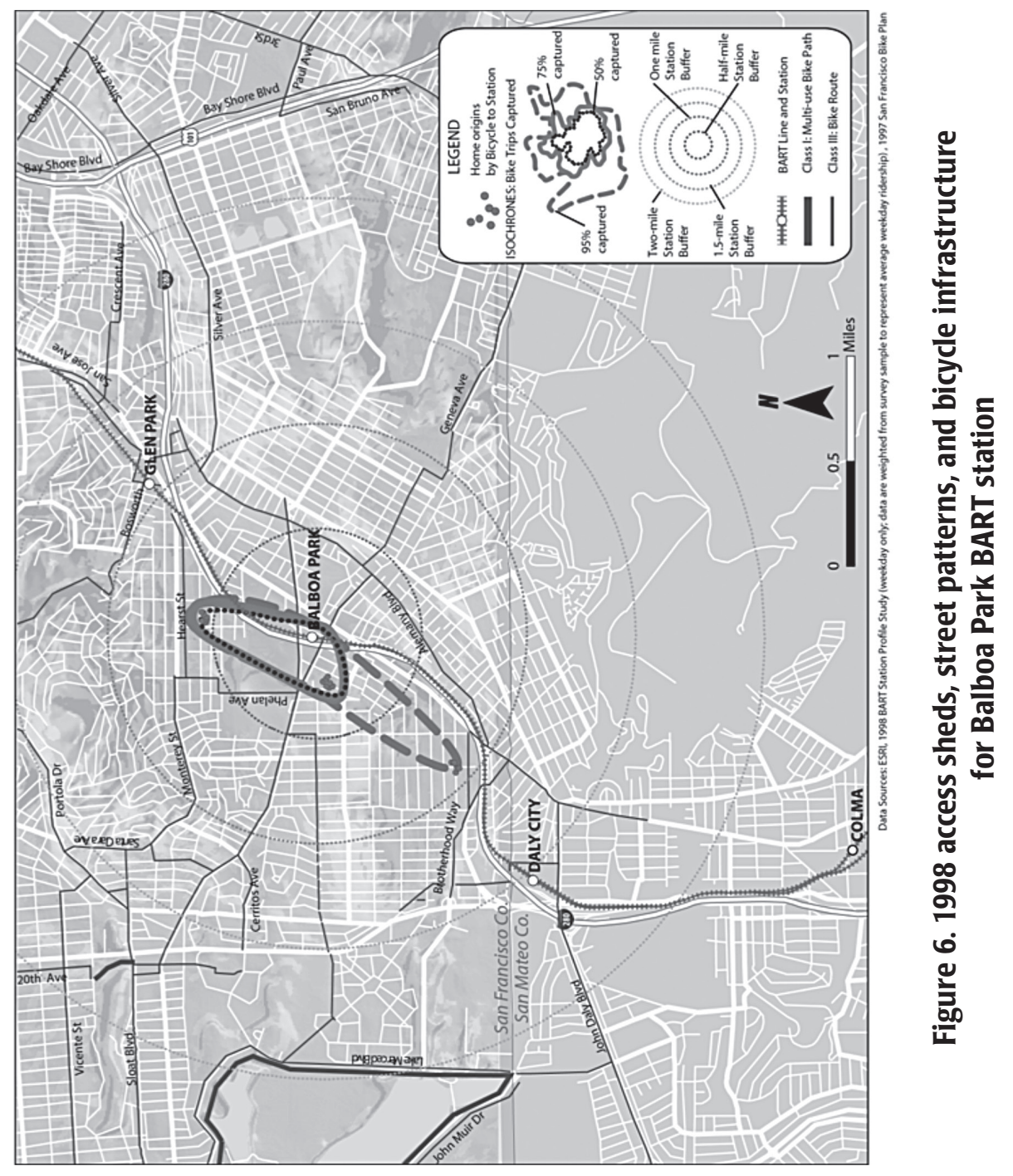




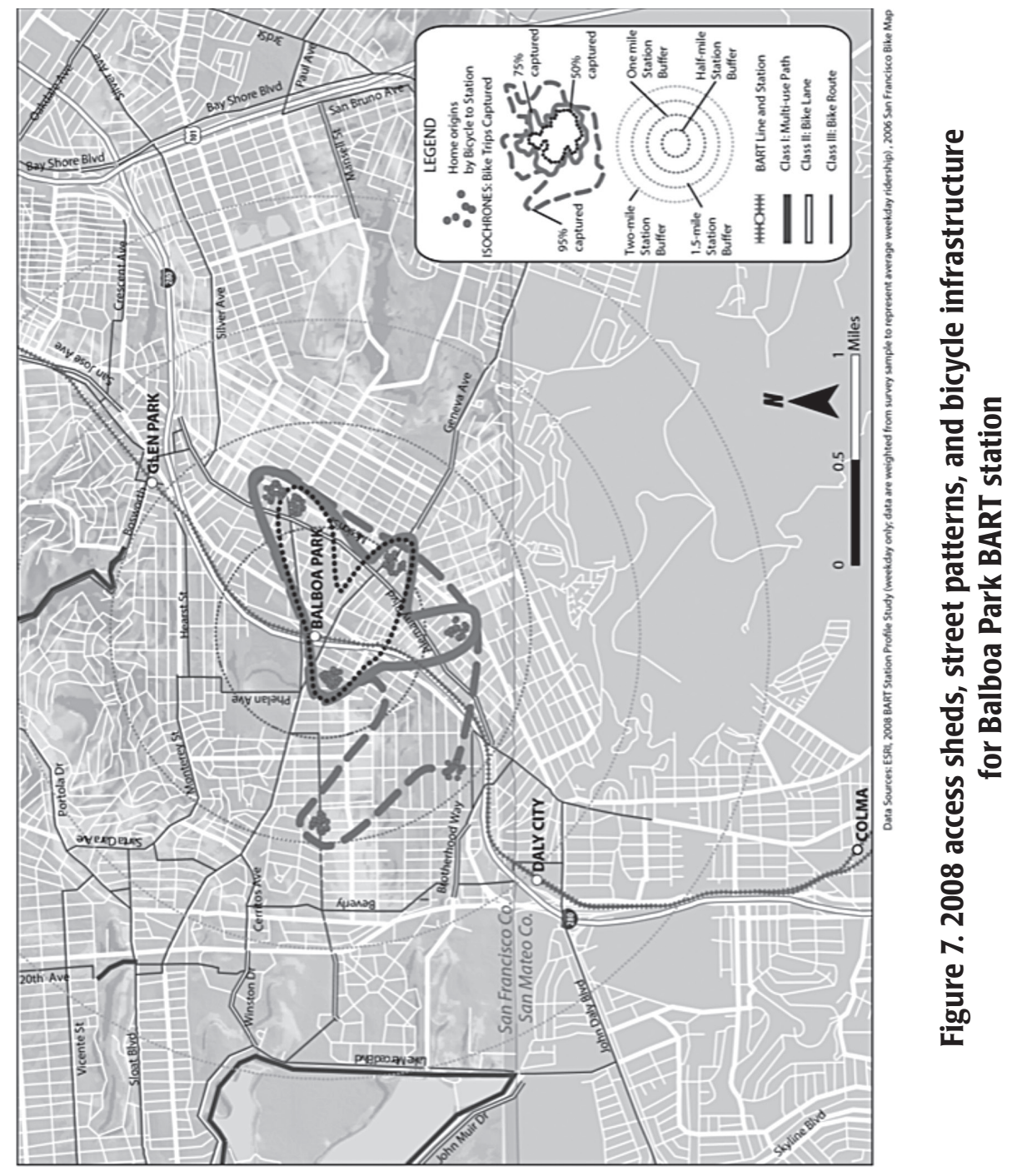




\section{Conclusion}

This paper's case experiences largely tell a story of "build it and they will come." If bicycles are to play a significant mobility role for accessing rail stations in the U.S., safe, secure, and well-designed bicycle infrastructure will be needed. This conclusion, drawn from case-based assessments, is supported by other research that has stressed the importance of separate, protected facilities in encouraging cycling more broadly (Dill and Voros 2007; Krizek et al. 2007; Buehler and Pucher 2012). It is also consistent with a recent regression-based model prepared for BART that showed, among the system's 42 stations, the presence of bike stations and increases in bike rack and electronic locker spaces were statistically associated with increased bicycle access trips to BART (Fehr and Peers 2012). Such improvements are not "amenities" but rather basic "provisions," not unlike the provisions for safe and convenient facilities provided to park-and-riders. Dutch and Danish cities show that directing significant shares of municipal budgets into bicycle and pedestrian improvements translates into significant shares of trips being made by non-motorized modes (Beatley 2000; Cervero 2003).

Some have noted that bike-and-ride becomes problematic when it is most successful (Pucher and Buehler 2009). Cities with high transit usage and levels of cycling face on-board capacity constraints. In contrast to the U.S., where the majority of cyclists take their bikes on board, in Europe cyclists mostly park their bikes at stations. The provision of ample, sheltered, secure bike parking at stations encourages this (Pucher and Buehler 2008), as does bike-sharing at destination stations.

Bicycles can and, we would argue, should play a stepped-up role in providing access to rail stations in many parts of the U.S. Money freed up from not having to expand park-and-ride facilities is one obvious funding source. So are regional, state, and federal funding programs that aim to improve urban air quality or promote sustainable mobility more broadly. Part of the success at the Ashby and Fruitvale Stations lies in collaborative efforts among multiple stakeholder interests. This took the form of the rail agency itself coordinating activities with bicycling and environmental advocacy groups and surrounding municipalities to plan, design, and build high-quality bike infrastructure, on-site and near-site. In the case of the Fruitvale station, bicycling improvements were part of a larger urban-regeneration campaign to build a vibrant, mixed-use transit village. As is often the case in the urban transportation field, the "hardware" component of high-quality bicycle facilities was matched by supportive "software," notably effective collaborations among 
stakeholder interests, to make bike-and-ride a respectable option for accessing rail stops.

\section{Acknowledgement}

We thank Val Menotti of BART for making survey data available to support this study. We also thank Bruce Appleyard for his help in conceptualizing bike accesssheds.

\section{References}

BART (Bay Area Rapid Transit). 2002. BART Bicycle Access and Parking Plan. Oakland: San Francisco Bay Area Rapid Transit System, agency report.

BART. 2006. Access BART. Oakland: San Francisco Bay Area Rapid Transit System, agency report.

Beatley, Timothy. 2000. Green Urbanism: Learning from European Cities. Washington, DC: Island Press.

Bernick, Michael S., and Robert Cervero. 1997. Transit Villages for the 21st Century. New York: McGraw-Hill.

Buehler, Ralph, and John Pucher. 2012. Cycling to work in 90 large American cities: New evidence on the role of bike paths and lanes. Transportation 29: 409-432.

Calthorpe, Peter. 1993. The New American Metropolis: Ecology, Community, and the American Dream. New York: Princeton Architectural Press.

Cervero, Robert. 1995. Rail Access Modes and Catchment Areas for the BART System. Berkeley: Institute of Urban and Regional Development, Monograph 50, University of California.

Cervero, Robert. 2001. Walk-and-ride: factors influencing pedestrian access to transit. Journal of Public Transportation 3(4): 1-23.

Cervero, Robert. 2003. Green connectors: Off-shore examples. Planning 69(5): 25-29.

Cervero, Robert, and John Landis. 1997. Twenty years of BART: Land use and development impacts. Transportation Research A 31(4): 309-333. 
Cervero, Robert, G. B. Arrington, Janet Smith-Heimer, and Robert Dunphy. 2005. Transit Oriented Development in America: Experiences, Challenges, and Prospects. Washington, DC: Transit Cooperative Research Program, Report, 102.

Dill, Jennifer, and Kim Voros. 2007. Factors affecting bicycling demand: Initial survey findings from the Portland, Oregon region. Transportation Research Record 2031: 9-17.

Eisen Letunic. 2012. BART Bicycle Plan: Modeling Access to Transit. Oakland: San Francisco Bay Area Rapid Transit System.

Fehr and Peers. 2012. BART Bicycle Access Plan Update: BART Bicycle Access Direct Ridership Model Development. Oakland: Bay Area Rapid Transit System.

Krizek, Kevin J., Ahmed El-Geneidy, and Kristin Thompson. 2007. A detailed analysis of how an urban trail system affects cyclists' travel. Transportation 34: 611-624.

Martens, Karel. 2004. The Bicycle as a feedering mode: Experiences from three European countries. Transportation Research D 9: 281-294.

Martens, Karel. 2007. Promoting bike-and-ride: The Dutch experience. Transportation Research A 41: 326-338.

Parsons Brinckerhoff. 2010. Metrorail Bicycle \& Pedestrian Access Improvements Study. Washington, DC: Washington Metropolitan Area Transit Authority.

Pucher, John, and Ralph Buehler. 2008. Making cycling irresistible: Lessons from The Netherlands, Denmark and Germany. Transport Reviews 28(4): 495-528.

Pucher, John, and Ralph Buehler. 2009. Integrating bicycling and public transport in North America. Journal of Public Transportation 12(3): 79-104.

Pucher, John, and Ralph Buehler. 2010. Walking and cycling for healthy cities. Built Environment 36(4): 391-414.

Pucher, John, Ralph Buehler, David R. Bassett, and Andrew L. Dannenberg. 2010. Walking and cycling to health: A comparative analysis of city, state, and international data. American Journal of Public Health 100(10): 1986-1992.

Pucher, John, Ralph Buehler, and Mark Seinen. 2011. Bicycling renaissance in North America? An update and re-appraisal of cycling trends and policies. Transportation Research A 45: 451-475.

Rietveld, Piet. 2000. The accessibility of railway stations: The role of the bicycle in The Netherlands. Transportation Research D 5: 71-75. 
The Unity Council. 2012. Fruitvale Transit Village Project. Partnerships, Enhancements, and Public Involvement. Washington, DC: Federal Highway Administration, Office of Planning, Environment and Realty, U.S. Department of Transportation.

Webber, Melvin M. 1976. The BART experience: What have we learned? The Public Interest 45: 79-108.

Weissman, Dana. 2012. The City of Berkeley Bicycle Counts: Summary of Trends, 2000-2012. Berkeley: Master Degree Client Report, Department of City and Regional Planning, University of California.

Yin, Robert K. 1994. Case Study Research: Design and Methods. Thousand Oaks: Sage Publications.

\section{About the Authors}

Robert Cervero (robertc@berkeley.edu) is Professor of City and Regional Planning in the Department of City and Regional Planning at the University of California, Berkeley, where he also holds the Carmel P. Freisen Chair in Urban Studies and serves as Director of the Institute of Urban and Regional Development (IURD) and the University of California Transportation Center (UCTC).

Benjamin CALDWell (bencaldwell9@gmail.com) is a graduate student in the City and Regional Planning program at the University of California, Berkeley and has worked as a bicycle planner for the City of San Francisco.

Jesus CUelLAR (jcuellar07@berkeley.edu) is a graduate student in the City and Regional Planning and the Transportation Engineering programs at the University of California, Berkeley. 